\title{
Review
}

\section{Role of Cardiac Magnetic Resonance Imaging in the Evaluation of Athletes with Premature Ventricular Beats}

\author{
Giulia Brunetti, Alberto Cipriani (D), Martina Perazzolo Marra, Manuel De Lazzari (D), Barbara Bauce (D), \\ Chiara Calore, Ilaria Rigato, Francesca Graziano, Riccardo Vio, Domenico Corrado * and Alessandro Zorzi $\mathbb{D}$
}

Citation: Brunetti, G.; Cipriani, A.; Perazzolo Marra, M.; De Lazzari, M.; Bauce, B.; Calore, C.; Rigato, I.; Graziano, F.; Vio, R.; Corrado, D.; et al. Role of Cardiac Magnetic Resonance Imaging in the Evaluation of Athletes with Premature Ventricular Beats. J. Clin. Med. 2022 11, 426. https://doi.org/10.3390/ jcm11020426

Academic Editors: Edoardo Conte and Andrea Igoren Guaricci

Received: 30 November 2021

Accepted: 6 January 2022

Published: 14 January 2022

Publisher's Note: MDPI stays neutral with regard to jurisdictional claims in published maps and institutional affiliations.

Copyright: (C) 2022 by the authors. Licensee MDPI, Basel, Switzerland. This article is an open access article distributed under the terms and conditions of the Creative Commons Attribution (CC BY) license (https:// creativecommons.org/licenses/by/ $4.0 /)$
Department of Cardiac, Thoracic and Vascular Sciences and Public Health, University of Padova, Via Giustiniani 2, 35128 Padova, Italy; giulia.brunetti@studenti.unipd.it (G.B.); alberto.cipriani@unipd.it (A.C.); martina.perazzolomarra@unipd.it (M.P.M.); manuel.delazzari@aopd.veneto.it (M.D.L.); barbara.bauce@unipd.it (B.B.); chiara.calore@aopd.veneto.it (C.C.); ilaria.rigato@aopd.veneto.it (I.R.); francesca.graziano.1@studenti.unipd.it (F.G.); riccardo.vio@studenti.unipd.it (R.V.); alessandro.zorzi@unipd.it (A.Z.)

* Correspondence: domenico.corrado@unipd.it

\begin{abstract}
Premature ventricular beats (PVBs) in athletes are not rare. The risk of PVBs depends on the presence of an underlying pathological myocardial substrate predisposing the subject to sudden cardiac death. The standard diagnostic work-up of athletes with PVBs includes an examination of family and personal history, resting electrocardiogram (ECG), $24 \mathrm{~h}$ ambulatory ECG (possibly with a 12-lead configuration and including a training session), maximal exercise testing and echocardiography. Despite its fundamental role in the diagnostic assessment of athletes with PVBs, echocardiography has very limited sensitivity in detecting the presence of non-ischemic left ventricular scars, which can be revealed only through more in-depth studies, particularly with the use of contrast-enhanced cardiac magnetic resonance (CMR) imaging. The morphology, complexity and exercise inducibility of PVBs can help estimate the probability of an underlying heart disease. Based on these features, CMR imaging may be indicated even when echocardiography is normal. This review focuses on interpreting PVBs, and on the indication and role of CMR imaging in the diagnostic evaluation of athletes, with a special focus on non-ischemic left ventricular scars that are an emerging substrate of cardiac arrest during sport.
\end{abstract}

Keywords: cardiac magnetic resonance; ventricular arrhythmias; sudden cardiac death; sports cardiology; athletes; preparticipation screening

\section{Introduction}

Adolescents and young adults engaged in competitive sports are at increased risk of sudden cardiac death (SCD) compared with their sedentary counterparts. Sport activity can act as a trigger for life-threatening ventricular arrhythmias (VAs) in athletes with an underlying cardiovascular disease, predisposing them to adrenergic-induced ventricular fibrillation [1-4]. Some authors have hypothesized that intense exercise may aggravate underlying pathological myocardial substrates or even cause an exercise-induced cardiomyopathy [5-7].

Documentation of premature ventricular beats (PVBs) on 12-lead electrocardiography (ECG), ambulatory ECG monitoring or ECG stress tests should raise the suspicion of an underlying cardiomyopathy. PVBs with common morphologies such as infundibular or fascicular ectopic beats are often not associated with structural cardiac abnormalities, whereas other PVBs may represent a red flag for the presence of a pathological substrate and must be properly investigated [8,9]. Standard examinations, including echocardiography, may fail to detect structural arrhythmic substrates such as a non-ischemic left ventricular scar (NLVS), which can only be detected by contrast-enhanced cardiac magnetic resonance (CMR) imaging. 
This review focuses on interpreting PVBs, and on the indication and role of CMR imaging in the diagnostic evaluation of athletes, with a special focus on non-ischemic left ventricular scars that are an emerging substrate of cardiac arrest during sport.

\section{Substrates of PVBs in Athletes}

Malignant arrhythmic events may occur in athletes with a structurally normal heart as a result of genetic channelopathies [10], some of which can be suspected based on ECG abnormalities (e.g., long and short QT syndromes and J wave syndromes), while others need exercise testing to be unmasked (e.g., catecholaminergic polymorphic ventricular tachycardia). The latter condition is a genetic ion channel disease leading to increased calcium release from the sarcoplasmic reticulum following adrenergic stimulation [11]. The disease should be suspected if exercise elicits PVBs with multiple morphologies (both RBBB- and LBBB-like) that worsen in number and complexity with increasing effort [12].

In master athletes (age $>35$ years), the most important arrhythmic substrate is ischemic heart disease. Male master endurance athletes, even with a low atherosclerotic risk profile, are more likely to have a higher CAC score compared with sedentary males with a similar risk profile [13]; the meaning of this observation is still uncertain. Exercise testing in athletes

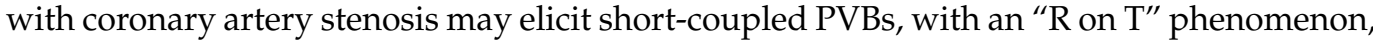
which may trigger runs of non-sustained polymorphic ventricular tachycardia (VT). In our experience, this peculiar arrhythmic pattern may be the only sign of underlying myocardial ischemia even in the absence of ST segment depression or chest pain.

Beyond channelopathies and ischemic heart disease, different structural cardiomyopathies can be associated with PVBs, including genetic and acquired heart muscle diseases. Hypertrophic cardiomyopathy (HCM) has been reported to cause more than one third of SCDs in the USA $[14,15]$, while arrhythmogenic cardiomyopathy (ACM) accounts for approximately one fourth of the cases in the Veneto region of Italy $[1,3,16]$. In most cases, first (history, physical examination, ECG) and second-level testing (stress test ECG, ambulatory ECG and echocardiography) is enough to exclude an underlying cardiomyopathy; however, some concealed arrhythmic substrates can be missed unless advanced imaging tests are used.

NLVSs have been associated with cardiac arrest occurring during effort $[17,18]$. In 2016, Di Gioia et al. reported a postmortem series of young SCD victims and found that NLVSs accounted for $25 \%$ of sport-related fatalities, while they were uncommon substrates in events unrelated to sports [19]. Interestingly, the scar was often associated with histopathologic evidence of fibrofatty replacement of the right ventricular myocardium, suggesting that the NLVS may be the expression of a biventricular ACM rather than the result of prior myocarditis. Biventricular myocardial fibrosis was found in the postmortem examination of a famous Italian footballer who died suddenly during a competition [20]. No matter the cause, a NLVS should be regarded as clinically significant because it is a possible substrate for macro-reentrant VT [21-24].

Non-ischemic myocardial fibrosis, in contrast to the ischemic one, involves the midmural and subepicardial myocardial layers but spares the endocardium. Since the latter contributes most to myocardial contractility, echocardiographic wall motion evaluation has limited sensitivity in detecting the presence of a NLVS [25]. ECG abnormalities such as low QRS voltages in the limb leads ("peak-to-peak" QRS amplitude $<0.5 \mathrm{mV}$ ) and/or $T$ wave inversion in the left precordial leads are associated with an underlying NLVS on CMR, even if their sensitivity does not exceed $20-30 \%$. The association between low QRS voltages and LV scars has been explained by the replacement of the LV myocardial mass with electrically inert fibrous tissue [26].

\section{Role of CMR in the Diagnostic Work-Up of Athletes with PVBs}

Cardiac magnetic resonance is the gold standard for the assessment of biventricular volume, mass and global and regional function $[27,28]$; LV function can be quantified using simplified CMR approaches such as biplanar long-axis views or short-axis stacks [29], 
and normal reference values for biventricular size and function have been published for the general population [30] and for athletes [31]. In addition to volume and function assessment, cine-CMR allows a more confident evaluation of regional abnormalities (such as asymmetric hypertrophy, hallmarks of HCM or the presence of crypts, diverticula or aneurysms); moreover, multiplanar cine-CMR can be used to assess valve morphology and function, and the aortic root with the evaluation of the origin and course of coronary arteries [32].

Recently, myocardial strain analysis on feature-tracking CMR, following the footsteps of speckle-tracking echocardiography, has emerged as a surrogate marker of LV systolic function, analyzing the deformation of a fixed myocardial point through the cardiac cycle; it is of prognostic value in different cardiomyopathies such as HCM, dilated cardiomyopathy, ischemic cardiomyopathy or myocarditis [33-38].

Beyond the role of functional indices, CMR offers the unique ability to identify myocardial tissue abnormalities that may have been missed by other imaging techniques. Tissue abnormalities typical of cardiomyopathies reflect chronic injury, inflammation, infiltration or abnormal storage that can be disclosed by specific CMR sequences. Standard CMR techniques for tissue characterization include T2-weighted CMR images, with an increased signal intensity reflecting inflammation-related myocardial edema [39,40]; T1-weighted blackblood images, where fat appears as a hyperintense bright signal; and contrast-enhanced T1-weighted scans performed after intravenous administration of gadolinium-based contrast agents, which has emerged as a widely available technique to enable visualization and quantification of myocardial fibrous tissue.

Over the last two decades, it has been demonstrated that a higher scar volume quantified with late gadolinium enhancement (LGE) predicts the risk of life-threatening VA recurrence in patients with aborted SCD [41], and the complexity of VAs in patients with non-ischemic cardiomyopathy referred for ablation of PVBs [42]. A recent meta-analysis of the impact of LGE on various cardiovascular outcomes both in ischemic and non-ischemic cardiomyopathies concluded that the presence of LGE was strongly associated with SCD and VAs [21]. The presence of LGE with a subepicardial/midmyocardial distribution without the diagnostic features of a specific cardiac disease is defined as an "isolated NLVS" (Figure 1). Although an isolated NLVS is traditionally interpreted as the consequence of previous myocarditis [43], other diseases such as the left-dominant ACM or cardiac involvement in sarcoidosis may manifest with this LGE pattern on CMR [44-48]. Some studies have reported a higher prevalence of NLVSs in endurance athletes compared to controls, suggesting that high-intensity exercise may cause cardiac fibrosis [49].

Myocardial mapping, a technique that has been recently introduced in clinical practice, allows measuring the different magnetic properties of each myocardial volume as expressed by magnetic relaxation times (native T1, T2, T2*) and the extracellular volume (ECV) derived from post-contrast T1. Changes in magnetic properties are typical of diseases characterized by intracellular cardiomyocyte disturbances (e.g., iron overload, or glycosphingolipid storage in Anderson-Fabry disease), extracellular disturbances in the myocardial interstitial tissue (e.g., myocardial fibrosis or amyloid deposit) or both (e.g., myocardial edema and/or infarction with increased intracellular and extracellular water) $[50,51]$. Conventional T1- or T2-weighted images require a subjective assessment, while mapping allows the quantification of the disease process. Differentiating cardiomyopathies from the physiologic adaptation of the athlete's heart is one of the emerging potential clinical uses of mapping techniques [52-55]. Since T1 mapping represents a novel marker of myocardial fibrosis, it may complement LGE in the evaluation of athletes with VAs, although scientific evidence is still lacking (Figure 2). 




Figure 1. A 40-year-old athlete presented with frequent PVBs on ECG ambulatory monitoring. Exercise test revealed frequent and repetitive monomorphic PVBs with RBBB/inferior axis morphology ((A), red asterisks). Post-contrast sequences on CMR showed an LGE subepicar$\mathrm{dial} /$ midmyocardial stria in the basal inferolateral and inferior LV walls (white triangles; (B) short-axis view; (C) 3-chamber view).

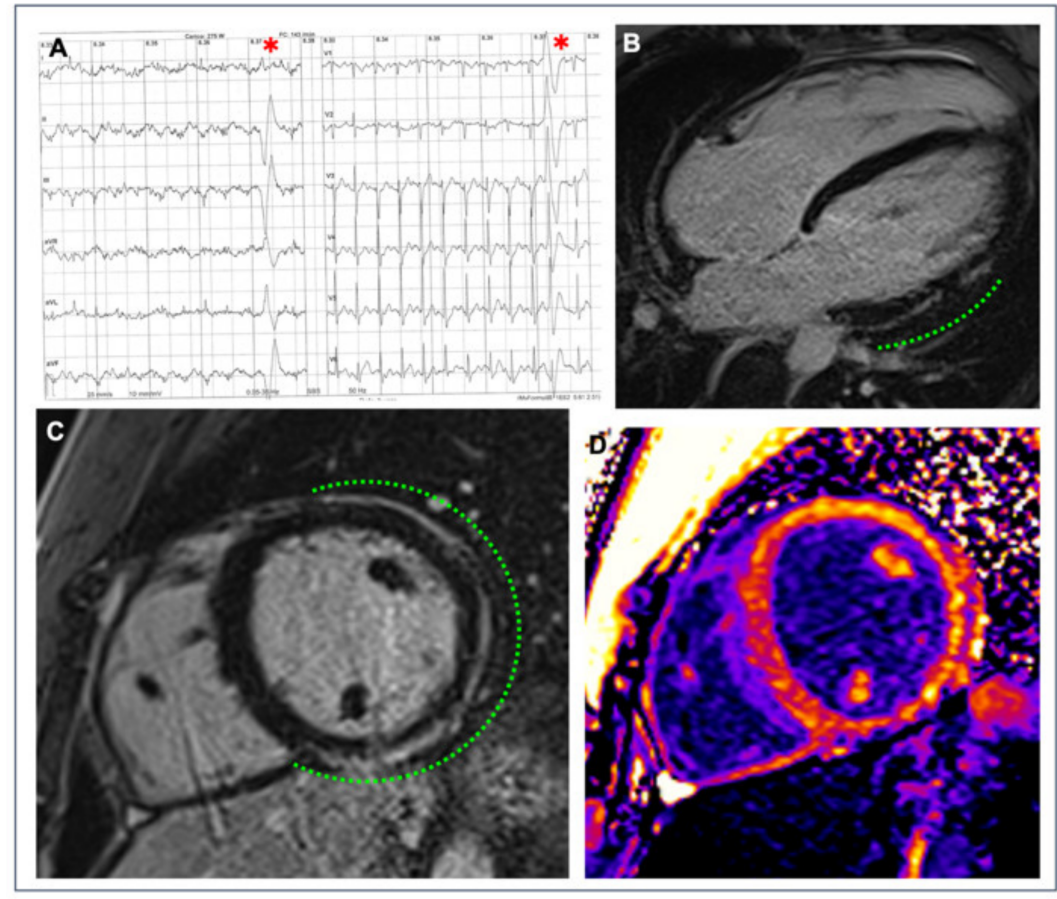

Figure 2. A 26-year-old competitive hockey player presented with frequent PVBs with right bundle branch block/superior axis morphology at high workload during exercise testing ((A), red asterisks). Post-contrast sequences on CMR revealed a subepicardial stria of LGE with a "ring-like" pattern, involving the anterior, lateral and inferior LV walls in their basal and medium portions (green dotted line; (B) 4-chamber view; (C) short-axis view); the presence of fibrous tissue is also confirmed by the increased signal in the correspondent areas in the native T1 mapping short-axis sequence (D). 
Finally, arrhythmogenic substrates characterized by inflammation, such as cardiac sarcoidosis, may be better disclosed by integrating CMR with nuclear imaging, particularly positron emission tomography (PET) [56,57]. Cardiac involvement in sarcoidosis can lead to inflammation and subsequent fibrosis that, on CMR, is characterized by multiple foci of LGE that may mimic ACM. In this subset, a recent study by Muser et al. demonstrated the usefulness of PET imaging, as compared to contrast-enhanced CMR, in accurately characterizing electroanatomic abnormalities responsible for VAs and potential targets for substrate ablation [58].

\section{Modern Interpretation of Premature Ventricular Beats in Athletes}

According to the current criteria for ECG interpretation in athletes, abnormalities are labeled as either "common" or "uncommon" $[59,60]$. The early repolarization pattern, for example, is included among the common abnormalities because it is related to training and found in a wide proportion of athletes because of the electrical remodeling of the heart in response to training. Conversely, $\mathrm{T}$ wave inversion in lateral leads is considered uncommon and unrelated to training because it is infrequently found in healthy athletes and thus requires an appropriate clinical work-up to exclude an underlying disease.

The modern classification of PVBs follows a similar approach: "common" PVBs are usually idiopathic (i.e., with a structurally normal heart), whereas "uncommon" PVBs carry a higher probability of an underlying myocardial disease (Table 1).

PVB morphology is the most relevant feature. Athletes with frequent PVBs in the absence of cardiac disease most often show a morphology suggesting a right or left ventricular (LV) outflow tract origin (i.e., left bundle branch block (LBBB)-like with a vertical axis pattern) or from the posterior fascicle of the left bundle branch (i.e., narrow QRS $(<130 \mathrm{~ms})$ with a right bundle branch block (RBBB)-like pattern and superior axis). These PVBs usually decrease during effort [61,62].

PVBs with an LBBB-like morphology and intermediate or superior axis (denoting a right ventricular (RV) or septal origin), and those with an RBBB-like morphology, wide QRS and superior axis (indicating an LV lateral wall origin), are classified as "uncommon" because they carry a higher risk of being associated with an underlying disease. The suspect is reinforced when arrhythmias increase in number or complexity during effort [16,65-69].

The traditional concept that arrhythmic risk is predicted by "PVB burden" (i.e., numerous PVBs are associated with a higher probability of malignant arrhythmic events) has been disproved by recent evidence. Indeed, it has been demonstrated that benign extrasystolic foci (more often located in the outflow tract) can give rise to a very high number of PVBs on $24 \mathrm{~h}$ Holter ECG in the absence of a pathological substrate [61,62]. Several studies have demonstrated the benign prognosis of PVBs originating from ventricular outflow tracts, even when numerous $[8,62,69]$, with the exception of the rare complication of tachycardiainduced LV dysfunction, the so-called "tachycardiomyopathy" [8,69-71]. Recent evidence suggests an inverse correlation between the number of PVBs and the probability of detecting a NLVS in patients with VAs, both in the general population [72] and athletes [73]. Consequently, the number of PVBs on ambulatory ECG monitoring is no longer deemed the main indication for further diagnostic testing to exclude a cardiomyopathy [9].

The evaluation of athletes with PVBs should take into consideration other clinical data: in particular, a positive family history of SCD or cardiomyopathy, history of unexplained syncope or the presence of other major ECG abnormalities (such as T wave inversion) on resting ECG. 
Table 1. Classification of PVBs morphology according to the probability of an underlying pathological myocardial substrate.

\begin{tabular}{|c|c|c|c|c|c|}
\hline $\begin{array}{l}\text { QRS } \\
\text { Morphology }\end{array}$ & $\begin{array}{l}\text { Probable } \\
\text { Origin of } \\
\text { PVB }\end{array}$ & $\begin{array}{l}\text { Disease } \\
\text { Probability }\end{array}$ & V1 Pattern & aVF Pattern & Refs. \\
\hline \multicolumn{6}{|l|}{ Common } \\
\hline $\begin{array}{l}\text { LBBB, late } \\
\text { precordial } \\
\text { transition } \\
\text { (R/S = } 1 \text { after } \\
\text { V3), inferior } \\
\text { axis. }\end{array}$ & $\begin{array}{l}\text { Right } \\
\text { ventricular } \\
\text { outflow tract. }\end{array}$ & $\begin{array}{l}\text { Usually } \\
\text { benign. }\end{array}$ & & & {$[8,61,62]$} \\
\hline $\begin{array}{l}\text { LBBB, } \\
\text { inferior axis, } \\
\text { small } \mathrm{R} \\
\text { waves in V1, } \\
\text { early } \\
\text { precordial } \\
\text { transition } \\
\text { (R/S = } 1 \text { by } \\
\text { V2 or V3). }\end{array}$ & $\begin{array}{l}\text { Left } \\
\text { ventricular } \\
\text { outflow tract. }\end{array}$ & $\begin{array}{l}\text { Usually } \\
\text { benign. }\end{array}$ & & & \\
\hline $\begin{array}{l}\text { QRS }<130 \mathrm{~ms} \\
\text { resembling a } \\
\text { typical } \\
\text { RBBB/left } \\
\text { anterior } \\
\text { fascicular } \\
\text { block. }\end{array}$ & $\begin{array}{l}\text { Left posterior } \\
\text { fascicle of the } \\
\text { left bundle } \\
\text { branch. }\end{array}$ & $\begin{array}{l}\text { Usually } \\
\text { benign. }\end{array}$ & & & [63] \\
\hline $\begin{array}{l}\text { QRS }<130 \mathrm{~ms} \\
\text { resembling a } \\
\text { typical } \\
\text { RBBB/left } \\
\text { posterior } \\
\text { fascicular } \\
\text { block. }\end{array}$ & $\begin{array}{l}\text { Left anterior } \\
\text { fascicle of the } \\
\text { left bundle } \\
\text { branch. }\end{array}$ & $\begin{array}{l}\text { Usually } \\
\text { benign. }\end{array}$ & & & \\
\hline \multicolumn{6}{|l|}{ Uncommon } \\
\hline $\begin{array}{l}\text { Atypical } \\
\text { RBBB, QRS } \\
\geq 130 \mathrm{~ms} \text {, } \\
\text { positive QRS } \\
\text { in V1-V6 and } \\
\text { inferior axis. }\end{array}$ & $\begin{array}{l}\text { Anterior } \\
\text { mitral } \\
\text { anulus/left } \\
\text { ventricular } \\
\text { outflow tract. }\end{array}$ & $\begin{array}{l}\text { Usually } \\
\text { benign but } \\
\text { may be } \\
\text { associated } \\
\text { with } \\
\text { myocardial } \\
\text { disease. }\end{array}$ & & & [64] \\
\hline $\begin{array}{l}\text { Atypical } \\
\text { RBBB, QRS } \\
\geq 130 \mathrm{~ms} \text {, } \\
\text { intermediate } \\
\text { or superior } \\
\text { axis. }\end{array}$ & $\begin{array}{l}\text { Left } \\
\text { ventricular } \\
\text { free wall. }\end{array}$ & $\begin{array}{l}\text { May be } \\
\text { associated } \\
\text { with } \\
\text { myocardial } \\
\text { disease. }\end{array}$ & & & {$[65,66]$} \\
\hline $\begin{array}{l}\text { LBBB, } \\
\text { superior or } \\
\text { intermediate } \\
\text { axis. }\end{array}$ & $\begin{array}{l}\text { Right } \\
\text { ventricular } \\
\text { free wall or } \\
\text { interventricu- } \\
\text { lar } \\
\text { septum. }\end{array}$ & $\begin{array}{l}\text { May be } \\
\text { associated } \\
\text { with } \\
\text { myocardial } \\
\text { disease. }\end{array}$ & & & \\
\hline
\end{tabular}




\section{Relationship between PVB Features and NLVS Revealed by CMR}

In the last year, $C M R$ imaging has been increasingly prescribed to investigate athletes with PVBs even when other clinical investigations (particularly echocardiography) are normal. This examination has led to the discovery of isolated NLVSs as the origin of PVBs in some cases that would otherwise have been considered idiopathic.

The first systematic study on athletes with VAs in association with an isolated NLVS was reported by Zorzi et al., in 2016 [25], although a small case series was previously described [74]. In this study, a large majority of the patients underwent CMR imaging for apparently idiopathic VAs, while only a minority did so because of ECG alterations (lateral T wave inversion and/or low QRS voltages) or echocardiographic abnormalities (lateral wall hypokinesia). In most cases, the PVB morphology was RBBB-like, wide QRS and superior axis, consistent with an origin from the LV lateral free wall. Significantly, during a mean follow-up of just over 3 years, major arrhythmic events such as appropriate defibrillator shock, sustained VT or SCD occurred in six (22\%) patients, mostly during sport activity. This finding underlines the role of adrenergic stimulation as an arrhythmic trigger in NLVSs. Recent evidence confirmed the association between NLVSs and VAs in athletes. A recent study by Lie et al. compared 43 high-performance competitive athletes with VAs to healthy athletes using clinical data and cardiac imaging and found a higher prevalence of non-ischemic LGE on CMR in athletes with VAs compared to healthy controls [75].

Several studies have demonstrated that PVB morphology and behavior during exercise can predict the presence of an underlying NLVS in athletes with apparently idiopathic VAs. Cipriani et al. reported CMR findings in a series of athletes with PVBs who were referred to a tertiary center [22]. Finding a myocardial scar (LGE) was three times more probable ( $47 \%$ vs. $17 \%$ ) if PVBs persisted or worsened during a stress test compared to those with a reduction in VAs at increasing workload. The other independent predictors of abnormal CMR were an RBBB-like morphology of PVBs and T wave inversion on resting ECG (Figure 3).

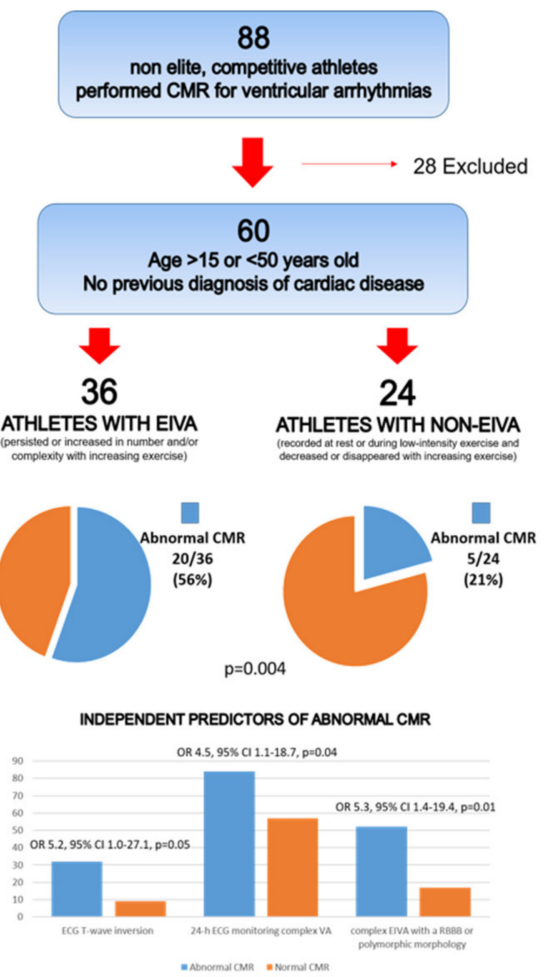

Figure 3. CMR: cardiac magnetic resonance; EIVA: exercise-induced ventricular arrhythmias; ECG: electrocardiogram; VA: ventricular arrhythmias; RBBB: right bundle branch block. Reproduced with permission from [22]. 
Another investigation aimed to evaluate the PVB burden in apparently healthy young athletes who volunteered to undergo a 12-lead $24 \mathrm{~h}$ Holter ECG, including a training session. Seventeen subjects were subsequently referred to CMR for frequent (>500/day), repetitive or training-induced PVBs [73]. In three cases, CMR demonstrated a NLVS: in all three, the PVBs showed an RBBB-like morphology with an inferior axis, and they were triggered by the exercise (Figure 4).

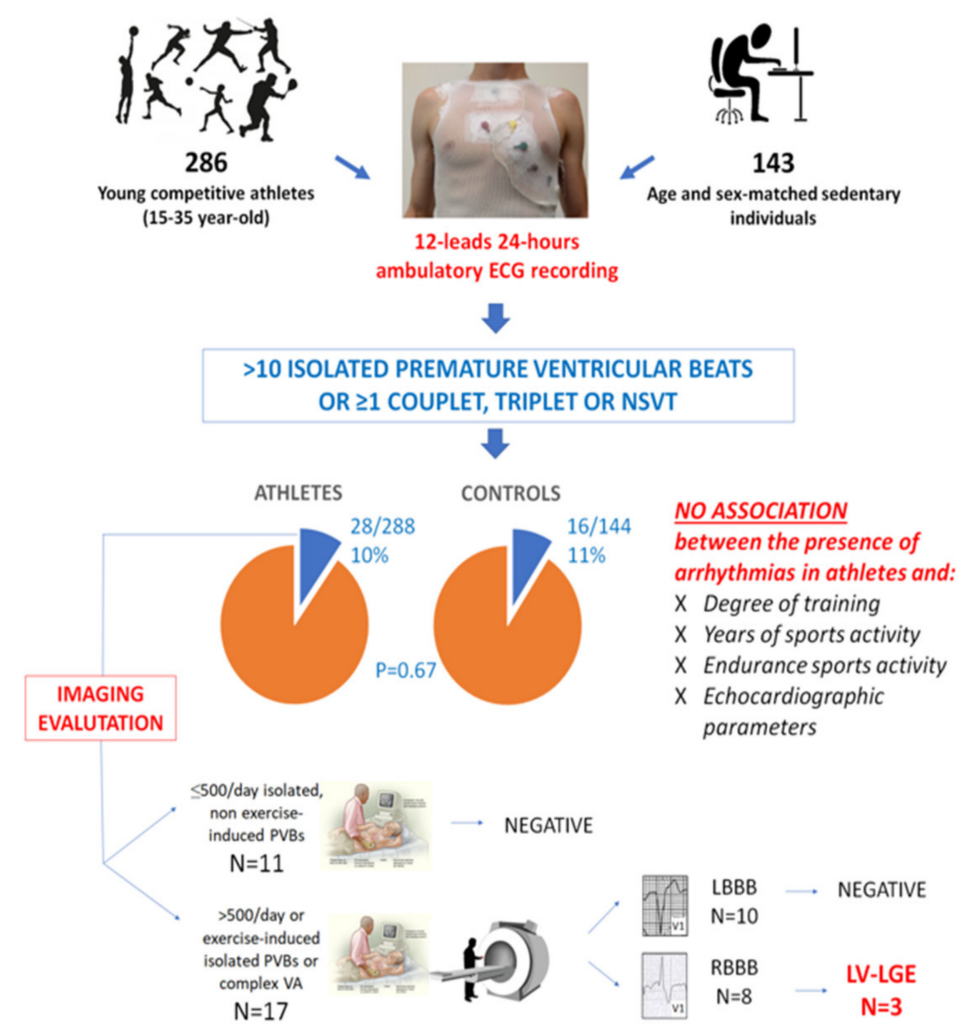

Figure 4. Summary of the main findings of a study enrolling 286 young competitive athletes and 143 healthy sedentary controls who volunteered to undergo 12-lead $24 \mathrm{~h}$ ambulatory ECG monitoring. LBBB, left bundle branch block; LGE, late gadolinium enhancement; LV, left ventricular; NSVT, nonsustained ventricular tachycardia; PVB, premature ventricular beat; RBBB, right bundle branch block; VA, ventricular arrhythmia. Reproduced with permission from [73].

In a multicenter study reporting on 251 competitive athletes with a negative family history and unremarkable ECG and normal echocardiography findings who underwent CMR for evaluation of VAs, LV LGE was found in $28(11 \%)$. The scar often showed a subepicardial/midmyocardial distribution (non-ischemic) and was more likely when PVBs depicted an RBBB-like pattern or multiple morphologies, or when non-sustained VT was recorded during exercise testing. Conversely, a high number of PVBs (>3300/day) predicted a normal CMR (Figure 5) [23].

The systematic evaluation of PVBs occurring during exercise testing increases the diagnostic sensitivity of preparticipation screening compared to traditional first-line investigations (history, physical examination and 12-lead ECG). In a population of 10,985 young athletes, adding exercise testing for VAs led to a 75\% increase in the diagnosis of pathological cardiac substrates, mainly NLVSs (Figure 6). The morphology of PVBs (RBBB-like or both RBBB and LBBB) and the occurrence of repetitive VAs during exercise correlated with an underlying NLVS at CMR [24]. 


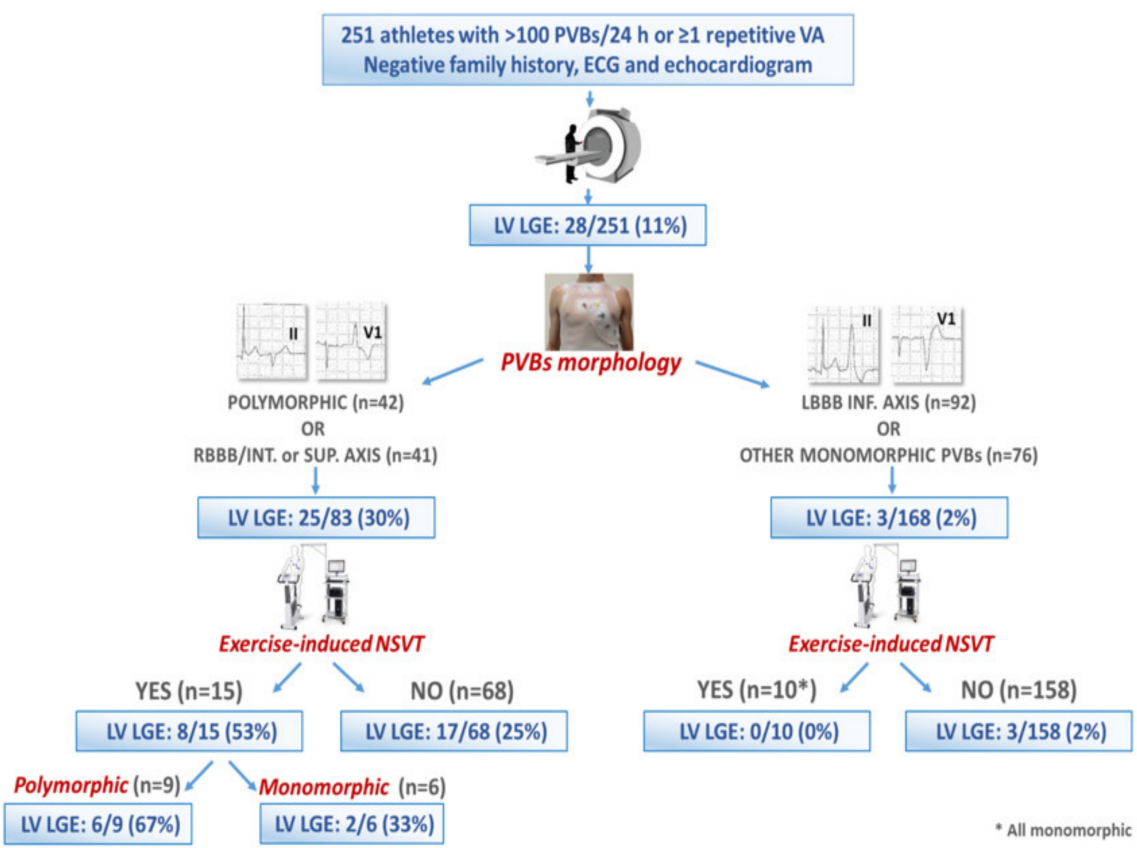

Figure 5. Summary of the main findings of a multicenter study on 251 athletes with ventricular arrhythmias, normal echocardiography and unremarkable ECG findings and a negative family history. Reproduced with permission from [23].

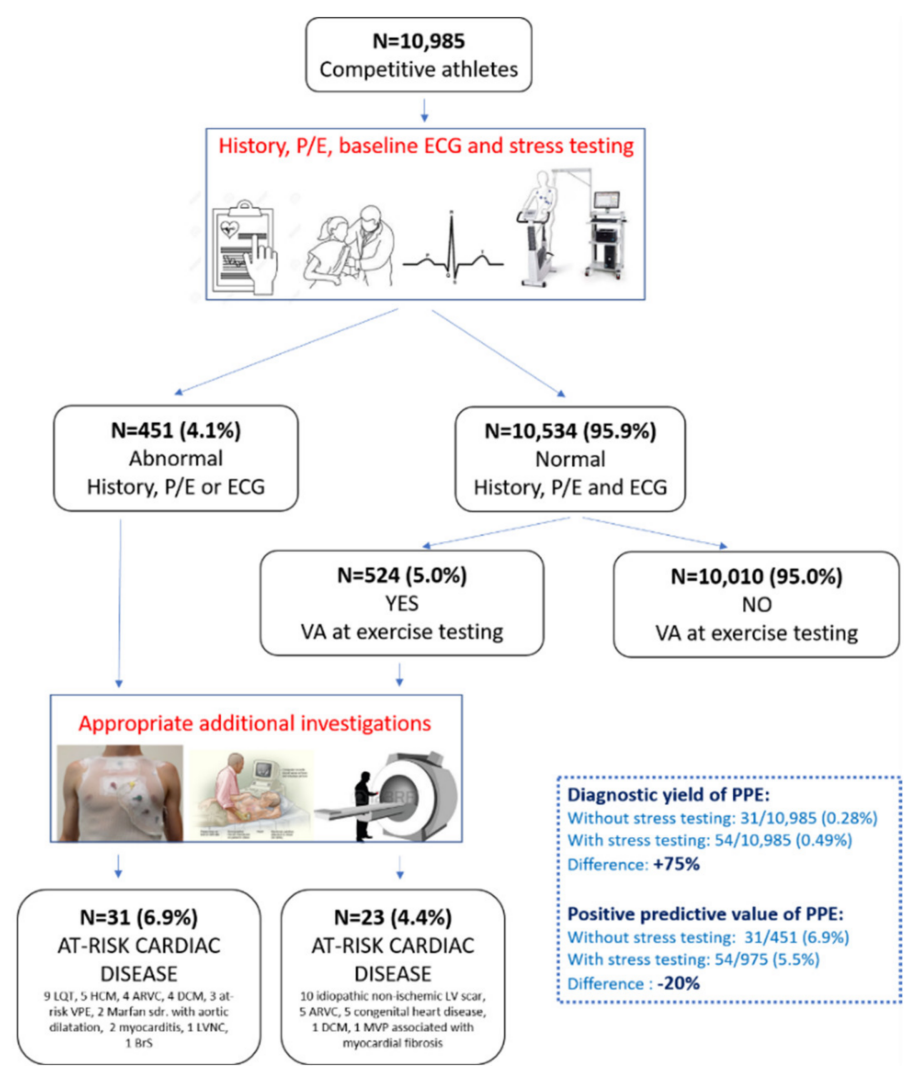

Figure 6. Summary of the main findings of a study investigating the additional value of exercise testing for ventricular arrhythmias in addition to history, physical examination and ECG in the setting of athletes' preparticipation screening. Reproduced with permission from [24]. 
Finally, the correlation between the characteristics of PVBs and the probability of an isolated NLVS as well as the prognostic significance of this CMR finding has also been documented in the general population. In a study by Muser et al. on 518 subjects with frequent PVBs, LGE was diagnosed by CMR in 16\%. Polymorphic PVBs and PVBs with a non-infundibular morphology were predictors of pathological myocardial substrates. Nearly one third of the subjects with LGE suffered major arrhythmic events during a median follow-up of 67 months (three died suddenly during effort), underscoring, once again, the precipitating role of adrenergic stimulation as an arrhythmic trigger in patients with a NLVS [76]. The same authors subsequently reported that the ring-like pattern of NLVSs, defined as subepicardial/midmyocardial LGE involving at least three contiguous LV segments in the same short-axis slice, was associated with a particularly ominous outcome [77].

In summary, NLVSs are a relevant substrate for malignant VAs, mostly for those occurring during sport activity. The two main PVB characteristics that should trigger CMR prescription to rule out an underlying scar in athletes with otherwise normal clinical findings are the morphology (particularly RBBB-like, wide QRS and superior axis) and the increase in number and complexity during exercise.

\section{Diagnostic Work-Up of PVBs in Athletes: When to Prescribe CMR}

In athletes with PVBs, a careful clinical examination is required to rule out an underlying myocardial disease that could potentially cause SCD. Although more recent recommendations suggest performing additional testing only when two or more PVBs are recorded on the resting ECG, we believe that even a single "uncommon" PVB should be considered as a red flag [78].

First-line investigations in athletes with PVBs should include history, physical examination, exercise testing, $24 \mathrm{~h}$ ambulatory ECG including a training session (possibly with a 12-lead system to allow PVBs morphology assessment) and echocardiography [9]. The presence of an abnormal resting ECG in athletes with PVBs significantly increases the probability of myocardial disease. The main ECG abnormalities linked to cardiomyopathies or channelopathies are repolarization abnormalities ( $\mathrm{T}$ wave inversion and ST segment depression), long QT, short QT, the Brugada pattern, conduction disturbances, ventricular pre-excitation and pathological $Q$ waves $[60,79]$. In addition, signal-averaged ECG, which records slow conduction in the myocardial area that can become a substrate for monomorphic VTs, may play a role in the diagnostic process $[80,81]$.

Exercise testing is a key tool for unmasking electrocardiographic abnormalities or arrhythmias absent at baseline. The effort should be maximal, and the test should be carried out until muscular exhaustion, not just limited to $85 \%$ of the predicted maximal heart rate. This is important not only for the documentation of ischemic ST-T changes, but also for eliciting adrenergic-dependent PVBs that may occur only at the peak of effort. Echocardiography is essential to rule out valvular defects, cardiomyopathies, congenital disorders and the anomalous origin of coronary arteries [82,83].

In case one of the above investigations is abnormal, additional tests may be needed based on clinical suspicion (e.g., CMR to rule out a possible cardiomyopathy, or a coronary computed tomography angiogram to exclude an ischemic cardiomyopathy). If first-line investigations are normal, indications for CMR depend on the characteristics of the PVBs (morphology, complexity and relation to exercise) that have been discussed above. Figure 7 shows a proposal of the diagnostic work-up of athletes with PVBs [9]. 


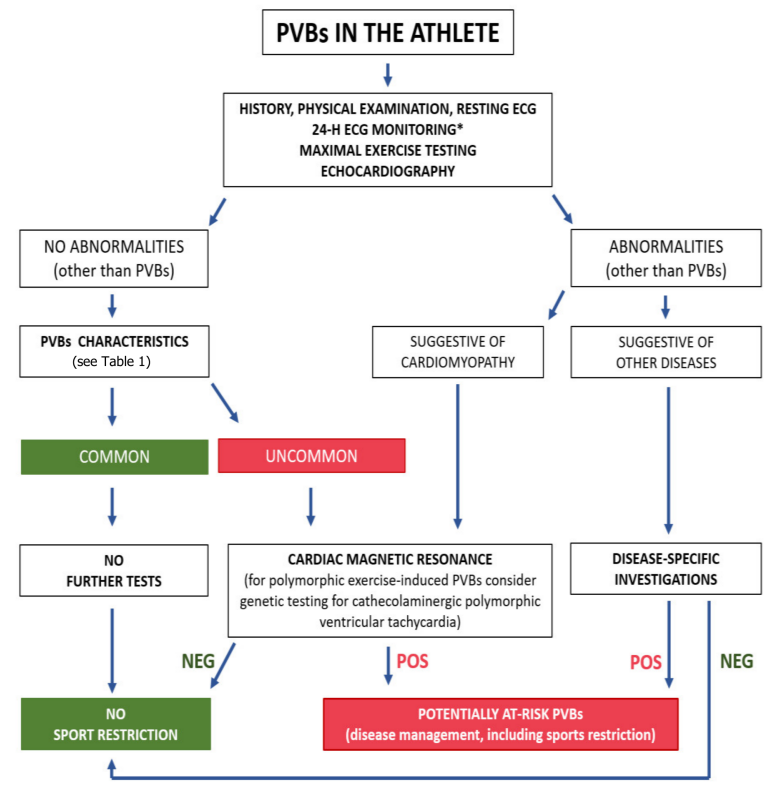

Figure 7. Proposed algorithm for evaluation of athletes with premature ventricular beats. * Twentyfour-hour ECG monitoring should ideally have a 12-lead configuration and include a training session. NEG, negative; POS, positive; PVBs, premature ventricular beats. Reproduced with permission from [9].

\section{Potential Pitfalls in Interpretation of CMR in Athletes}

When analyzing CMR imaging, attention must be paid to some pitfalls. It is known that CMR shows systematically larger chamber dimensions and volumes, but a smaller wall thickness and mass, compared with echocardiography [84]; thus, caution should be exercised in applying echocardiographic-derived reference values when performing CMR in athletes [31]. The presence of LGE should be confirmed in two orthogonal planes, and care must be taken in using the correct time-for-inversion (TI) to obtain the maximal contrast between normal myocardium and scar tissue; moreover, bright ghosting artifacts can result from poor ECG gating or poor breath holding. In addition, it is conventionally considered problematic to detect LGE at the level of the thin RV wall, even though newer generation CMR machines enhance the ability to identify RV intramyocardial scar tissue.

Not all non-ischemic LGE patterns should be considered markers of disease. Isolated right ventricular insertion point (or "junctional") LGE, i.e., LGE confined to the insertion points of the right ventricle to the anterior and/or posterior ventricular septum, has been described in many pathological conditions such as pulmonary hypertension [85] or hypertrophic cardiomyopathy [86], but it is also commonly found in healthy athletes, especially those engaged in endurance disciplines [87-89]. In this subset, its prevalence reaches up to $30 \%$, and it may reflect the tension on insertion points due to pressure and volume overload on the right ventricle during intensive exercise [49]. In subjects without additional evidence of cardiac disease, it should not be considered pathological [90]. Finally, a mid-wall stria of LGE in the basal portion of the interventricular septum may reflect a septal perforator coronary artery, rather than myocardial fibrosis; this must be taken into account in order to prevent cardiac disease overdiagnosis [91].

\section{Recommendations for Competitive Sport Eligibility in Athletes with NLVSs}

In both the European Society of Cardiology and the American Heart Association guidelines on competitive athletes, NLVSs are addressed in the myocarditis chapter [92,93]. The European document recognizes that myocardial scars can be the source of life-threatening VAs. Accordingly, competitive sport activity is not recommended in athletes with a NLVS associated with LV dysfunction or clinically relevant arrhythmias (frequent or complex PVBs). At present, there is no evidence that isolated LGE is associated with an increased risk 
of SCD during exercise, but athletes should at least remain under clinical surveillance [93]. Similarly, the American Heart Association's recommendations suggest restricting sport activity in athletes with a NLVS and ventricular dysfunction or relevant arrhythmias. They also state the following: "at present, it is unresolved whether resolution of myocarditisrelated LGE should be required to permit return to competitive sports" [93].

\section{Conclusions}

Systematic investigations of athletes with PVBs through CMR imaging in recent years have served to clarify that substrates of SCD, particularly NLVSs, may be missed in routine clinical tests. In the presence of at-risk PVB characteristics, based on their morphology, complexity and relation to effort, CMR should be performed even when echocardiography and baseline ECG are normal. Besides standard CMR scans and post-contrast images, novel techniques such as mapping and feature tracking are also emerging in the subset of athletes' evaluation.

Beyond NLVS, ischemic heart disease represents an important substrate of VAs, especially in master athletes. In the evaluation of older athletes with PVBs, stress CMR in addition to the standard CMR protocol might be useful for ruling out coronary artery stenosis, although further studies are needed to evaluate its diagnostic value in this peculiar clinical setting.

Funding: This research received no external funding.

Conflicts of Interest: The authors declare no conflict of interest.

\section{References}

1. Corrado, D.; Basso, C.; Pavei, A.; Michieli, P.; Schiavon, M.; Thiene, G. Trends in sudden cardiovascular death in young competitive athletes after implementation of a preparticipation screening program. J. Am. Med. Assoc. 2006, 296, 1593-1601. [CrossRef] [PubMed]

2. De Noronha, S.V.; Sharma, S.; Papadakis, M.; Desai, S.; Whyte, G.; Sheppard, M.N. Etiology of sudden cardiac death in athletes in the United Kingdom: A pathological study. Heart 2009, 95, 1409-1414. [CrossRef]

3. Corrado, D.; Basso, C.; Rizzoli, G.; Schiavon, M.; Thiene, G. Does Sports Activity Enhance the Risk of Sudden Death in Adolescents and Young Adults? J. Am. Coll. Cardiol. 2003, 42, 1959-1963. [CrossRef]

4. Thiene, G.; Rizzo, S.; Schiavon, M.; Maron, M.S.; Zorzi, A.; Corrado, D.; Maron, B.J.; Basso, C. Structurally Normal Hearts Are Uncommonly Associated with Sudden Deaths in Athletes and Young People. J. Am. Coll. Cardiol. 2019, 73, 3031-3032. [CrossRef] [PubMed]

5. Benito, B.; Gay-Jordi, G.; Serrano-Mollar, A.; Guasch, E.; Shi, Y.; Tardif, J.C.; Brugada, J.; Nattel, S.; Mont, L. Cardiac arrhythmogenic remodeling in a rat model of long-term intensive exercise training. Circulation 2011, 123, 13-22. [CrossRef]

6. Heidbuchel, H. The athlete's heart is a proarrhythmic heart, and what that means for clinical decision making. Europace 2018, 20, 1401-1411. [CrossRef]

7. Sharma, S.; Merghani, A.; Mont, L. Exercise and the heart: The good, the bad, and the ugly. Eur. Heart J. 2015, 36, 1445-1453. [CrossRef] [PubMed]

8. Gaita, F.; Giustetto, C.; Di Donna, P.; Richiardi, E.; Libero, L.; Brusin, M.C.R.; Molinari, G.; Trevi, G. Long-term follow-up of right ventricular monomorphic extrasystoles. J. Am. Coll. Cardiol. 2001, 38, 364-370. [CrossRef]

9. Corrado, D.; Drezner, J.A.; D'Ascenzi, F.; Zorzi, A. How to evaluate premature ventricular beats in the athlete: Critical review and proposal of a diagnostic algorithm. Br. J. Sports Med. 2020, 54, 1142-1148. [CrossRef]

10. Basso, C.; Carturan, E.; Pilichou, K.; Rizzo, S.; Corrado, D.; Thiene, G. Sudden cardiac death with normal heart: Molecular autopsy. Proc. Cardiovasc. Pathol. 2010, 19, 321-325. [CrossRef]

11. Sutanto, H.; Lyon, A.; Lumens, J.; Schotten, U.; Dobrev, D.; Heijman, J. Cardiomyocyte calcium handling in health and disease: Insights from in vitro and in silico studies. Prog. Biophys. Mol. Biol. 2020, 157, 54-75. [CrossRef]

12. Priori, S.G.; Napolitano, C.; Memmi, M.; Colombi, B.; Drago, F.; Gasparini, M.; DeSimone, L.; Coltorti, F.; Bloise, R.; Keegan, R.; et al. Clinical and molecular characterization of patients with catecholaminergic polymorphic ventricular tachycardia. Circulation 2002, 106, 69-74. [CrossRef] [PubMed]

13. Merghani, A.; Maestrini, V.; Rosmini, S.; Cox, A.T.; Dhutia, H.; Bastiaenan, R.; David, S.; Yeo, T.J.; Narain, R.; Malhotra, A.; et al. Prevalence of Subclinical Coronary Artery Disease in Masters Endurance Athletes with a Low Atherosclerotic Risk Profile. Circulation 2017, 136, 126-137. [CrossRef]

14. Camp, S.P.V.; Bloor, C.M.; Mueller, F.O.; Cantu, R.C.; Olson, H.G. Nontraumatic sports death in high school and college athletes. Med. Sci. Sports Exerc. 1995, 27, 641-647. [CrossRef] [PubMed] 
15. Maron, B.J.; Haas, T.S.; Doerer, J.J.; Thompson, P.D.; Hodges, J.S. Comparison of U.S. and Italian Experiences with Sudden Cardiac Deaths in Young Competitive Athletes and Implications for Preparticipation Screening Strategies. Am. J. Cardiol. 2009, 104, 276-280. [CrossRef]

16. Thiene, G.; Nava, A.; Corrado, D.; Rossi, L.; Pennelli, N. Right Ventricular Cardiomyopathy and Sudden Death in Young People. N. Engl. J. Med. 1988, 318, 129-133. [CrossRef]

17. Pilichou, K.; Mancini, M.; Rigato, I.; Lazzarini, E.; Giorgi, B.; Carturan, E.; Bauce, B.; D'Amati, G.; Marra, M.P.; Basso, C. Nonischemic left ventricular scar sporadic or familial? Screen the genes, scan the mutation carriers. Circulation 2014, 130, e180-e182. [CrossRef]

18. Whyte, G.; Sheppard, M.; George, K.; Shave, R.; Wilson, M.; Prasad, S.; O'Hanlon, R.; Sharma, S. Post-mortem evidence of idiopathic left ventricular hypertrophy and idiopathic interstitial myocardial fibrosis: Is exercise the cause? Br. J. Sports Med. 2009, 2009. [CrossRef]

19. Di Gioia, C.R.T.; Giordano, C.; Cerbelli, B.; Pisano, A.; Perli, E.; De Dominicis, E.; Poscolieri, B.; Palmieri, V.; Ciallella, C.; Zeppilli, P.; et al. Nonischemic left ventricular scar and cardiac sudden death in the young. Hum. Pathol. 2016, 58, 78-89. [CrossRef] [PubMed]

20. D'Amati, G.; De Caterina, R.; Basso, C. Sudden cardiac death in an Italian competitive athlete: Pre-participation screening and cardiovascular emergency care are both essential. Int. J. Cardiol. 2016, 206, 84-86. [CrossRef]

21. Ganesan, A.N.; Gunton, J.; Nucifora, G.; McGavigan, A.D.; Selvanayagam, J.B. Impact of Late Gadolinium Enhancement on mortality, sudden death and major adverse cardiovascular events in ischemic and nonischemic cardiomyopathy: A systematic review and meta-analysis. Int. J. Cardiol. 2018, 254, 230-237. [CrossRef]

22. Cipriani, A.; Zorzi, A.; Sarto, P.; Donini, M.; Rigato, I.; Bariani, R.; De Lazzari, M.; Pilichou, K.; Thiene, G.; Iliceto, S.; et al Predictive value of exercise testing in athletes with ventricular ectopy evaluated by cardiac magnetic resonance. Heart Rhythm 2019, 16, 239-248. [CrossRef]

23. Crescenzi, C.; Zorzi, A.; Vessella, T.; Martino, A.; Panattoni, G.; Cipriani, A.; De Lazzari, M.; Marra, M.P.; Fusco, A.; Sciarra, L.; et al. Predictors of left ventricular scar using cardiac magnetic resonance in athletes with apparently idiopathic ventricular arrhythmias. J. Am. Heart Assoc. 2021, 10, e018206. [CrossRef]

24. Zorzi, A.; Vessella, T.; De Lazzari, M.; Cipriani, A.; Menegon, V.; Sarto, G.; Spagnol, R.; Merlo, L.; Pegoraro, C.; Marra, M.P.; et al. Screening young athletes for diseases at risk of sudden cardiac death: Role of stress testing for ventricular arrhythmias. Eur. J. Prev. Cardiol. 2020, 27, 311-320. [CrossRef]

25. Zorzi, A.; Marra, M.P.; Rigato, I.; De Lazzari, M.; Susana, A.; Niero, A.; Pilichou, K.; Migliore, F.; Rizzo, S.; Giorgi, B.; et al. Nonischemic left ventricular scar as a substrate of life-threatening ventricular arrhythmias and sudden cardiac death in competitive athletes. Circ. Arrhythmia Electrophysiol. 2016, 9, e004229. [CrossRef]

26. De Lazzari, M.; Zorzi, A.; Cipriani, A.; Susana, A.; Mastella, G.; Rizzo, A.; Rigato, I.; Bauce, B.; Giorgi, B.; Lacognata, C.; et al. Relationship between electrocardiographic findings and cardiac magnetic resonance phenotypes in arrhythmogenic cardiomyopathy. J. Am. Heart Assoc. 2018, 7, e009855. [CrossRef]

27. Hundley, W.G.; Bluemke, D.A.; Finn, J.P.; Flamm, S.D.; Fogel, M.A.; Friedrich, M.G.; Ho, V.B.; Jerosch-Herold, M.; Kramer, C.M.; Manning, W.J.; et al. ACCF/ACR/AHA/NASCI/ SCMR 2010 expert consensus document on cardiovascular magnetic resonance: A report of the American College of Cardiology Foundation Task Force on Expert Consensus Documents. J. Am. Coll. Cardiol. 2010, 55, 2614-2662. [CrossRef]

28. Leiner, T.; Bogaert, J.; Friedrich, M.G.; Mohiaddin, R.; Muthurangu, V.; Myerson, S.; Powell, A.J.; Raman, S.V.; Pennell, D.J. SCMR Position Paper (2020) on clinical indications for cardiovascular magnetic resonance. J. Cardiovasc. Magn. Reson. 2020, 22, 76. [CrossRef] [PubMed]

29. Maceira, A.M.; Prasad, S.K.; Khan, M.; Pennell, D.J. Normalized left ventricular systolic and diastolic function by steady state free preces- sion cardiovascular magnetic resonance. J. Cardiovasc. Magn. Reson. 2006, 8, 417-426. [CrossRef] [PubMed]

30. Petersen, S.E.; Aung, N.; Sanghvi, M.M.; Zemrak, F.; Fung, K.; Paiva, J.M.; Francis, J.M.; Khanji, M.Y.; Lukaschuk, E.; Lee, A.M.; et al. Reference ranges for cardiac structure and function using cardiovascular magnetic resonance (CMR) in Caucasians from the UK Biobank population cohort. J. Cardiovasc. Magn. Reson. 2017, 19, 18. [CrossRef] [PubMed]

31. D'Ascenzi, F.; Anselmi, F.; Piu, P.; Fiorentini, C.; Carbone, S.F.; Volterrani, L.; Focardi, M.; Bonifazi, M.; Mondillo, S. Cardiac Magnetic Resonance Normal Reference Values of Biventricular Size and Function in Male Athlete's Heart. JACC Cardiovasc. Imaging 2019, 12, 1755-1765. [CrossRef] [PubMed]

32. Pelliccia, A.; Caselli, S.; Sharma, S.; Basso, C.; Bax, J.J.; Corrado, D.; D'Andrea, A.; D'Ascenzi, F.; Di Paolo, F.M.; Edvardsen, T.; et al Internal reviewers for EAPC and EACVI. European Association of Preventive Cardiology (EAPC) and European Association of Cardiovascular Imaging (EACVI) joint position statement: Recommendations for the indication and interpretation of cardiovascular imaging in the evaluation of the athlete's heart. Eur. Heart J. 2018, 39, 1949-1969. [CrossRef] [PubMed]

33. Erley, J.; Genovese, D.; Tapaskar, N.; Alvi, N.; Rashedi, N.; Besser, S.A.; Kawaji, K.; Goyal, N.; Kelle, S.; Lang, R.M.; et al. Echocardiography and cardiovascular magnetic resonance based evaluation of myocardial strain and relationship with late gadolinium enhancement. J. Cardiovasc. Magn. Reson. 2019, 21, 46. [CrossRef]

34. Tower-Rader, A.; Mohananey, D.; To, A.; Lever, H.M.; Popovic, Z.B.; Desai, M.Y. Prognostic value of global longitudinal strain in hypertrophic cardio- myopathy: A systematic review of existing literature. JACC Cardiovasc. Imaging 2018, 12, 1930-1942. [CrossRef] 
35. Fischer, K.; Obrist, S.J.; Erne, S.A.; Stark, A.W.; Marggraf, M.; Kaneko, K.; Guensch, D.P.; Huber, A.T.; Greulich, S.; Aghayev, A.; et al. Feature Tracking Myocardial Strain Incrementally Improves Prognostication in Myocarditis Beyond Traditional CMR Imaging Features. JACC Cardiovasc. Imaging. 2020, 13, 1891-1901. [CrossRef]

36. Negri, F.; Muser, D.; Driussi, M.; Sanna, G.D.; Masè, M.; Cittar, M.; Poli, S.; De Bellis, A.; Fabris, E.; Puppato, M.; et al. Prognostic role of global longitudinal strain by feature tracking in patients with hypertrophic cardiomyopathy: The STRAIN-HCM study. Int. J. Cardiol. 2021, 345, 61-67. [CrossRef]

37. Mordi, I.; Bezerra, H.; Carrick, D.; Tzemos, N. The Combined Incremental Prognostic Value of LVEF, Late Gadolinium Enhancement, and Global Circumferential Strain Assessed by CMR. JACC Cardiovasc. Imaging 2015, 8, 540-549. [CrossRef]

38. Romano, S.; Judd, R.M.; Kim, R.J.; Kim, H.W.; Klem, I.; Heitner, J.F.; Shah, D.J.; Jue, J.; White, B.E.; Indorkar, R.; et al. FeatureTracking Global Longitudinal Strain Predicts Death in a Multicenter Population of Patients with Ischemic and Nonischemic Dilated Cardiomyopathy Incremental to Ejection Fraction and Late Gadolinium Enhancement. JACC Cardiovasc. Imaging 2018, 11, 1419-1429. [CrossRef]

39. Gagliardi, M.G.; Bevilacqua, M.; Di Renzi, P.; Picardo, S.; Passariello, R.; Marcelletti, C. Usefulness of magnetic resonance imaging for diagnosis of acute myocarditis in infants and children, and comparison with endomyocardial biopsy. Am. J. Cardiol. 1991, 68, 1089-1091. [CrossRef]

40. Abdel-Aty, H.; Boyé, P.; Zagrosek, A.; Wassmuth, R.; Kumar, A.; Messroghli, D.; Bock, P.; Dietz, R.; Friedrich, M.G.; Schulz-Menger, J. Diagnostic performance of cardiovascular magnetic resonance in patients with suspected acute myocarditis: Comparison of different approaches. J. Am. Coll. Cardiol. 2005, 45, 1815-1822. [CrossRef]

41. Neilan, T.G.; Farhad, H.; Mayrhofer, T.; Shah, R.V.; Dodson, J.A.; Abbasi, S.A.; Danik, S.B.; Verdini, D.J.; Tokuda, M.; Tedrow, U.B.; et al. Late gadolinium enhancement among survivors of sudden cardiac arrest. JACC Cardiovasc. Imaging 2015, 8 , 414-423. [CrossRef] [PubMed]

42. Ghannam, M.; Siontis, K.C.; Cochet, H.; Jais, P.; Juhoor, M.; Attili, A.; Sharaf-Dabbagh, G.; Latchamsetty, R.; Jongnarangsin, K.; Morady, F.; et al. Risk stratification in patients with nonischemic cardiomyopathy and ventricular arrhythmias based on quantification of intramural delayed enhancement on cardiac magnetic resonance imaging. J. Cardiovasc. Electrophysiol. 2020, 31, 1762-1769. [CrossRef] [PubMed]

43. Friedrich, M.G.; Sechtem, U.; Schulz-Menger, J.; Holmvang, G.; Alakija, P.; Cooper, L.T.; White, J.A.; Abdel-Aty, H.; Gutberlet, M.; Prasad, S.; et al. Cardiovascular Magnetic Resonance in Myocarditis: A JACC White Paper. J. Am. Coll. Cardiol. 2009, 53, 1475-1487. [CrossRef]

44. Corrado, D.; Van Tintelen, P.J.; McKenna, W.J.; Hauer, R.N.W.; Anastastakis, A.; Asimaki, A.; Basso, C.; Bauce, B.; Brunckhorst, C.; Bucciarelli-Ducci, C.; et al. Arrhythmogenic right ventricular cardiomyopathy: Evaluation of the current diagnostic criteria and differential diagnosis. Eur. Heart J. 2020, 41, 1414-1429. [CrossRef]

45. Cipriani, A.; Perazzolomarra, M.; Bariani, R.; Mattesi, G.; Vio, R.; Bettella, N.; de Lazzari, M.; Motta, R.; Bauce, B.; Zorzi, A.; et al Differential diagnosis of arrhythmogenic cardiomyopathy: Phenocopies versus disease variants. Minerva Med. 2021, 112, 269-280. [CrossRef] [PubMed]

46. Marra, M.P.; De Lazzari, M.; Zorzi, A.; Migliore, F.; Zilio, F.; Calore, C.; Vettor, G.; Tona, F.; Tarantini, G.; Cacciavillani, L.; et al Impact of the presence and amount of myocardial fibrosis by cardiac magnetic resonance on arrhythmic outcome and sudden cardiac death in nonischemic dilated cardiomyopathy. Heart Rhythm 2014, 11, 856-863. [CrossRef] [PubMed]

47. Corrado, D.; Marra, M.P.; De Lazzari, M.; Cipriani, A.; Zorzi, A. Diagnosis and Prognosis of Arrhythmogenic Left Ventricular Cardiomyopathy. J. Am. Coll. Cardiol. 2020, 76, 1387-1388. [CrossRef]

48. Corrado, D.; Marra, M.P.; Zorzi, A.; Beffagna, G.; Cipriani, A.; De Lazzari, M.; Migliore, F.; Pilichou, K.; Rampazzo, A.; Rigato, I.; et al. Diagnosis of arrhythmogenic cardiomyopathy: The Padua criteria. Int. J. Cardiol. 2020, 319, 106-114. [CrossRef]

49. Malek, L.A.; Bucciarelli-Ducci, C. Myocardial fibrosis in athletes-Current perspective. Clin. Cardiol. 2020, 43, 882-888. [CrossRef]

50. Messroghli, D.R.; Moon, J.C.; Ferreira, V.M.; Grosse-Wortmann, L.; He, T.; Kellman, P.; Mascherbauer, J.; Nezafat, R.; Salerno, M.; Schelbert, E.B.; et al. Clinical recommendations for cardiovascular magnetic resonance mapping of T1, T2, T2* and extracellular volume: A consensus statement by the Society for Cardiovascular Magnetic Resonance (SCMR) endorsed by the European Association for Cardiovascular Imaging (EACVI). J. Cardiovasc. Magn. Reson. 2017, 19, 75. [CrossRef]

51. Ferreira, V.M.; Schulz-Menger, J.; Holmvang, G.; Kramer, C.M.; Carbone, I.; Sechtem, U.; Kindermann, I.; Gutberlet, M.; Cooper, L.T.; Liu, P.; et al. Cardiovascular magnetic resonance in nonischemic myocardial inflammation: Expert recommendations. J. Am. Coll. Cardiol. 2018, 72, 3158-3176. [CrossRef]

52. McDiarmid, A.K.; Swoboda, P.P.; Erhayiem, B.; Lancaster, R.E.; Lyall, G.K.; Broadbent, D.A.; Dobson, L.E.; Musa, T.A.; Ripley, D.P.; Garg, P.; et al. Athletic cardiac adaptation in males is a consequence of elevated myocyte mass. Circ. Cardiovasc. Imaging 2016, 9, e003579. [CrossRef]

53. Ellims, A.H.; Iles, L.M.; Ling, L.H.; Chong, B.; Macciocca, I.; Slavin, G.S.; Hare, J.L.; Kaye, D.M.; Marasco, S.F.; McLean, C.A.; et al. A comprehensive evaluation of myocardial fibrosis in hypertrophic cardiomyopathy with cardiac magnetic resonance imaging: Linking genotype with fibrotic phenotype. Eur. Heart J. Cardiovasc. Imaging 2014, 15, 1108-1116. [CrossRef]

54. Swoboda, P.P.; Erhayiem, B.; McDiarmid, A.K.; Lancaster, R.E.; Lyall, G.K.; Dobson, L.E.; Ripley, D.P.; Musa, T.A.; Garg, P.; Ferguson, C.; et al. Relationship between cardiac deformation parameters measured by cardiovascular magnetic resonance and aerobic fitness in endurance athletes. J. Cardiovasc. Magn. Reson. 2016, 18, 48. [CrossRef] 
55. Le, T.T.; Bryant, J.A.; Ang, B.W.Y.; Pua, C.J.; Su, B.; Ho, P.Y.; Lim, S.; Huang, W.; Lee, P.T.; Tang, H.C.; et al. The application of exercise stress cardiovascular magnetic resonance in patients with suspected dilated cardiomyopathy. J. Cardiovasc. Magn. Reson. 2020, 22, 10. [CrossRef] [PubMed]

56. Patel, M.R.; Cawley, P.J.; Heitner, J.F.; Klem, I.; Parker, M.A.; Jaroudi, W.A.; Meine, T.J.; White, J.B.; Elliott, M.D.; Kim, H.W.; et al. Detection of myocardial damage in patients with sarcoidosis. Circulation 2009, 120, 1969-1977. [CrossRef]

57. Ohira, H.; Tsujino, I.; Ishimaru, S.; Oyama, N.; Takei, T.; Tsukamoto, E.; Miura, M.; Sakaue, S.; Tamaki, N.; Nishimura, M. Myocardial imaging with 18F-fluoro-2-deoxyglucose positron emission tomography and magnetic resonance imaging in sarcoidosis. Eur. J. Nucl. Med. Mol. Imaging 2007, 35, 933-941. [CrossRef] [PubMed]

58. Muser, D.; Santangeli, P.; Liang, J.J.; Castro, S.A.; Magnani, S.; Hayashi, T.; Garcia, F.C.; Frankel, D.S.; Dixit, S.; Zado, E.S.; et al. Characterization of the Electroanatomic Substrate in Cardiac Sarcoidosis: Correlation with Imaging Findings of Scar and Inflammation. JACC Clin. Electrophysiol. 2018, 4, 291-303. [CrossRef]

59. Corrado, D.; Pelliccia, A.; Heidbuchel, H.; Sharma, S.; Link, M.; Basso, C.; Biffi, A.; Buja, G.; Delise, P.; Gussac, I.; et al Recommendations for interpretation of 12-lead electrocardiogram in the athlete. Eur. Heart J. 2010, 31, 243-259. [CrossRef] [PubMed]

60. Drezner, J.A.; Sharma, S.; Baggish, A.; Papadakis, M.; Wilson, M.G.; Prutkin, J.M.; La Gerche, A.; Ackerman, M.J.; Borjesson, M.; Salerno, J.C.; et al. International criteria for electrocardiographic interpretation in athletes: Consensus statement. Br. J. Sports Med. 2017, 51, 704-731. [CrossRef] [PubMed]

61. Niwano, S.; Wakisaka, Y.; Niwano, H.; Fukaya, H.; Kurokawa, S.; Kiryu, M.; Hatakeyama, Y.; Izumi, T. Prognostic significance of frequent premature ventricular contractions originating from the ventricular outflow tract in patients with normal left ventricular function. Heart 2009, 95, 1230-1237. [CrossRef]

62. Ventura, R.; Steven, D.; Klemm, H.U.; Lutomsky, B.; Müllerleile, K.; Rostock, T.; Servatius, H.; Risius, T.; Meinertz, T.; Willems, S.; et al. Decennial follow-up in patients with recurrent tachycardia originating from the right ventricular outflow tract: Electrophysiologic characteristics and response to treatment. Eur. Heart J. 2007, 28, 2338-2345. [CrossRef] [PubMed]

63. Sung, R.; Scheinman, M. Spectrum of Fascicular Arrhythmias. Card. Electrophysiol. Clin. 2016, 8, 567-580. [CrossRef] [PubMed]

64. Al'Aref, S.J.; Ip, J.E.; Markowitz, S.M.; Liu, C.F.; Thomas, G.; Frenkel, D.; Panda, N.C.; Weinsaft, J.W.; Lerman, B.B.; Cheung, J.W. Differentiation of papillary muscle from fascicular and mitral annular ventricular arrhythmias in patients with and without structural heart disease. Circ. Arrhythm. Electrophysiol. 2015, 8, 616-624. [CrossRef]

65. Buxton, A.E.; Marchlinski, F.E.; Doherty, J.U.; Cassidy, D.M.; Vassallo, J.A.; Flores, B.T.; Josephson, M.E. Repetitive, monomorphic ventricular tachycardia: Clinical and electrophysiologic characteristics in patients with and patients without organic heart disease. Am. J. Cardiol. 1984, 54, 997-1002. [CrossRef]

66. Verdile, L.; Maron, B.J.; Pelliccia, A.; Spataro, A.; Santini, M.; Biffi, A. Clinical significance of exercise-induced ventricular tachyarrhythmias in trained athletes without cardiovascular abnormalities. Heart Rhythm 2015, 12, 78-85. [CrossRef]

67. Morshedi-Meibodi, A.; Evans, J.C.; Levy, D.; Larson, M.G.; Vasan, R.S. Clinical correlates and prognostic significance of exerciseinduced ventricular premature beats in the community: The Framingham heart study. Circulation 2004, 109, 2417-2422. [CrossRef] [PubMed]

68. Steriotis, A.K.; Nava, A.; Rigato, I.; Mazzotti, E.; Daliento, L.; Thiene, G.; Basso, C.; Corrado, D.; Bauce, B. Noninvasive cardiac screening in young athletes with ventricular arrhythmias. Am. J. Cardiol. 2013, 111, 557-562. [CrossRef]

69. Rahilly, G.T.; Prystowsky, E.N.; Zipes, D.P.; Naccarelli, G.V.; Jackman, W.M.; Heger, J.J. Clinical and electrophysiologic findings in patients with repetitive monomorphic ventricular tachycardia and otherwise normal electrocardiogram. Am. J. Cardiol. 1982, 50, 459-468. [CrossRef]

70. Delise, P.; Sitta, N.; Lanari, E.; Berton, G.; Centa, M.; Allocca, G.; Cati, A.; Biffi, A. Long-term effect of continuing sports activity in competitive athletes with frequent ventricular premature complexes and apparently normal heart. Am. J. Cardiol. 2013, 112, 1396-1402. [CrossRef]

71. Biffi, A.; Pelliccia, A.; Verdile, L.; Fernando, F.; Spataro, A.; Caselli, S.; Santini, M.; Maron, B.J. Long-term clinical significance of frequent and complex ventricular tachyarrhythmias in trained athletes. J. Am. Coll. Cardiol. 2002, 40, 446-452. [CrossRef]

72. Nucifora, G.; Muser, D.; Masci, P.G.; Barison, A.; Rebellato, L.; Piccoli, G.; Daleffe, E.; Toniolo, M.; Zanuttini, D.; Facchin, D.; et al. Prevalence and prognostic value of concealed structural abnormalities in patients with apparently idiopathic ventricular arrhythmias of left versus right ventricular origin: A magnetic resonance imaging study. Circ. Arrhythmia Electrophysiol. 2014, 7, 456-462. [CrossRef] [PubMed]

73. Zorzi, A.; De Lazzari, M.; Mastella, G.; Niero, A.; Trovato, D.; Cipriani, A.; Peruzza, F.; Portolan, L.; Berton, G.; Sciacca, F.; et al. Ventricular arrhythmias in young competitive athletes: Prevalence, determinants, and underlying substrate. J. Am. Heart Assoc. 2018, 7, e009171. [CrossRef]

74. Schnell, F.; Claessen, G.; La Gerche, A.; Bogaert, J.; Lentz, P.A.; Claus, P.; Mabo, P.; Carré, F.; Heidbuchel, H. Subepicardial delayed gadolinium enhancement in asymptomatic athletes: Let sleeping dogs lie? Br. J. Sports Med. 2016, 50, 111-117. [CrossRef] [PubMed]

75. Lie, Ø.H.; Klaboe, L.G.; Dejgaard, L.A.; Skjølsvik, E.T.; Grimsmo, J.; Bosse, G.; Hopp, E.; Edvardsen, T.; Haugaa, K.H. Cardiac Phenotypes and Markers of Adverse Outcome in Elite Athletes with Ventricular Arrhythmias. JACC Cardiovasc. Imaging 2021, 14, 148-158. [CrossRef] 
76. Muser, D.; Santangeli, P.; Castro, S.A.; Arroyo, R.C.; Maeda, S.; Benhayon, D.A.; Liuba, I.; Liang, J.J.; Sadek, M.M.; Chahal, A.; et al. Risk Stratification of Patients with Apparently Idiopathic Premature Ventricular Contractions. JACC Clin. Electrophysiol. 2020, 6, 722-735. [CrossRef] [PubMed]

77. Muser, D.; Nucifora, G.; Pieroni, M.; Castro, S.A.; Arroyo, R.C.; Maeda, S.; Benhayon, D.A.; Liuba, I.; Sadek, M.; Magnani, S.; et al. Prognostic Value of Nonischemic Ringlike Left Ventricular Scar in Patients with Apparently Idiopathic Non-sustained Ventricular Arrhythmias. Circulation 2021, 143, 1359-1373. [CrossRef]

78. Sharma, S.; Drezner, J.A.; Baggish, A.; Papadakis, M.; Wilson, M.G.; Prutkin, J.M.; La Gerche, A.; Ackerman, M.J.; Borjesson, M.; Salerno, J.C.; et al. International Recommendations for Electrocardiographic Interpretation in Athletes. J. Am. Coll. Cardiol. 2018, 39, 1466-1480. [CrossRef]

79. Zorzi, A.; Calore, C.; Vio, R.; Pelliccia, A.; Corrado, D. Accuracy of the ECG for differential diagnosis between hypertrophic cardiomyopathy and athlete's heart: Comparison between the European Society of Cardiology (2010) and International (2017) criteria. Br. J. Sports Med. 2018, 52, 667-673. [CrossRef]

80. Gatzoulis, K.A.; Arsenos, P.; Trachanas, K.; Dilaveris, P.; Antoniou, C.; Tsiachris, D.; Sideris, S.; Kolettis, T.M.; Tousoulis, D. Signal-averaged electrocardiography: Past, present, and future. J Arrhythm. 2018, 34, 222-229. [CrossRef] [PubMed]

81. Gatzoulis, K.A.; Arsenos, P.; Antoniou, C.-K.; Dilaveris, P.; Sideris, S.; Tsiachris, D.; Doundoulakis, I.; Tsioufis, K.; Tousoulis, D Signal-averaged electrocardiogram findings among right ventricular arrhythmogenic cardiomyopathy (ARVC) patients: Do they have a place in ARVC management? Int. J. Cardiol. 2021, 322, 175. [CrossRef]

82. Zeppilli, P.; Russo, A.D.; Santini, C.; Palmieri, V.; Natale, L.; Giordano, A.; Frustaci, A. In vivo detection of coronary artery anomalies in asymptomatic athletes by echocardiographic screening. Chest 1998, 114, 89-93. [CrossRef]

83. Pelliccia, A.; Spataro, A.; Maron, B.J. Prospective echocardiographic screening for coronary artery anomalies in 1,360 elite competitive athletes. Am. J. Cardiol. 1993, 72, 978-979. [CrossRef]

84. Prakken, N.H.; Teske, A.J.; Cramer, M.J.; Mosterd, A.; Bosker, A.C.; Mali, W.P.; A Doevendans, P.; Velthuis, B.K. Head-to-head comparison between echocardiography and cardiac MRI in the evaluation of the athlete's heart. Br. J. Sports Med. 2012, 46, 348-354. [CrossRef] [PubMed]

85. De Lazzari, M.; Cipriani, A.; Rizzo, S.; Famoso, G.; Giorgi, B.; Tarantini, G.; Thiene, G.; Tona, F.; Iliceto, S.; Basso, C.; et al. Right Ventricular Junctional Late Gadolinium Enhancement Correlates with Outcomes in Pulmonary Hypertension. JACC Cardiovasc. Imaging 2019, 12, 936-938. [CrossRef] [PubMed]

86. Chan, R.H.; Maron, B.J.; Olivotto, I.; Assenza, G.E.; Haas, T.S.; Lesser, J.R.; Gruner, C.; Crean, A.M.; Rakowski, H.; Rowin, E.; et al. Significance of Late Gadolinium Enhancement at Right Ventricular Attachment to Ventricular Septum in Patients with Hypertrophic Cardiomyopathy. Am. J. Cardiol. 2015, 116, 436-441. [CrossRef] [PubMed]

87. La Gerche, A. Can intense endurance exercise cause myocardial damage and fibrosis? Curr. Sports Med. Rep. 2013, 12, 63-69. [CrossRef]

88. Van de Schoor, F.R.; Aengevaeren, V.L.; Hopman, M.T.E.; Oxborough, D.L.; George, K.P.; Thompson, P.D.; Eijsvogels, T.M.H. Myocardial Fibrosis in Athletes. Mayo Clin. Proc. 2016, 91, 1617-1631. [CrossRef] [PubMed]

89. Domenech-Ximenos, B.; La Garza, M.S.-D.; Prat-González, S.; Sepúlveda-Martínez, A.; Crispi, F.; Duran-Fernandez, K.; Perea, R.J.; Bijnens, B.; Sitges, M. Prevalence and pattern of cardiovascular magnetic resonance late gadolinium enhancement in highly trained endurance athletes. J. Cardiovasc. Magn. Reson. 2020, 22, 62. [CrossRef] [PubMed]

90. Grigoratos, C.; Pantano, A.; Meschisi, M.; Gaeta, R.; Ait-Ali, L.; Barison, A.; Todiere, G.; Festa, P.; Sinagra, G.; Aquaro, G.D. Clinical importance of late gadolinium enhancement at right ventricular insertion points in otherwise normal hearts. Int. $J$. Cardiovasc. Imaging 2020, 36, 913-920. [CrossRef] [PubMed]

91. Cipriani, A.; Fusaro, M.; De Conti, G.; Corrado, D.; Zorzi, A. Coronary artery branch misinterpreted as pathological septal late gadolinium enhancement: A common pitfall during evaluation of athletes with ventricular arrhythmias. Eur. Hear. J. Cardiovasc. Imaging 2021, jeab192. [CrossRef] [PubMed]

92. Pelliccia, A.; Solberg, E.E.; Papadakis, M.; Adami, P.E.; Biffi, A.; Caselli, S.; La Gerche, A.; Niebauer, J.; Pressler, A.; Schmied, C.M.; et al. Recommendations for participation in competitive and leisure time sport in athletes with cardiomyopathies, myocarditis, and pericarditis: Position statement of the Sport Cardiology Section of the European Association of Preventive Cardiology (EAPC). Eur. Heart J. 2019, 40, 19-33. [CrossRef] [PubMed]

93. Maron, B.J.; Udelson, J.E.; Bonow, R.O.; Nishimura, R.A.; Ackerman, M.J.; Estes, N.M.; Cooper, L.T., Jr.; Link, M.S.; Maron, M.S. Eligibility and Disqualification Recommendations for Competitive Athletes with Cardiovascular Abnormalities: Task Force 3: Hypertrophic Cardiomyopathy, Arrhythmogenic Right Ventricular Cardiomyopathy and Other Cardiomyopathies, and Myocarditis: A Scientific Statement From the American Heart Association and American College of Cardiology. Circulation 2015, 132, 2362-2371. [CrossRef] 